\title{
Ali Allawi's Perspective on Forging a Civilisational Presence
}

\author{
Karim D. Crow*
}

\begin{abstract}
Ali Allawi ${ }^{* *}$ is an Iraqi statesman who served in post-Saddam Iraq as Minister of Defense and then Minister of Finance and is currently a Senior Fellow at Harvard's Kennedy School of Government. In his book The Crisis of Islamic Civilization ${ }^{1}$ he gives a wake-up call for Muslims "to muster the inner resources of their faith to fashion a civilizing outer presence." He questions the very possibility of the survival and continuity of Islam's "transcendental ideal" in the face of profound challenges brought by modernity, globalisation, and impersonal technological and marketising forces. He is convinced that the prevailing orthodoxies should be seriously challenged in order to renew the transcendent aspect of Islam and rectify the over-identification of Islam with its political and juridical components. He soberly argues: "The calls to reform Islam and the meaning of reformation in the context of established orthodoxies have been highly problematic" (xv).
\end{abstract}

This is not a dry scholarly disquisition, but a lively gripping narrative by an engaged public intellectual and former government official who carefully observes the world of Islam and is intimate with both Islam's textual traditions and western Islamic studies. Blending history and economics with philosophy and sociology, he offers an intelligent analysis of a civilisation in crisis. Allawi states: "This book is about Islamic civilisation - a universe which is recognisably Islamic, draws its vitality and inspiration from the inner and outer aspects of Islam, and is the bridge connecting the two. It is this world that is in danger of disappearing" (xvi).

He serves us bitter medicine to guard against such a fatal outcome: "A new Islamic civilisation can only be carved out from a harsh reality of years of inactivity, lassitude and indifference. ... The creative impulses of civilisation are now all in the domain of another world order" (272). He asks for Muslims today to hold up a mirror to themselves: "What that mirror would show was a fading of their own civilisational drive and an increasingly obvious indifference to, and often abandonment of, the foundational ethical and spiritual bases of the faith" (xii)

Allawi downplays the importance of political Islam which he treats as "only an aspect of the overall problem of Islam in the modern world, ... a manifestation of the ailment rather than the ailment itself. What concerned me was to discover the deeper roots of the crisis and, in particular, to find out whether Islam's apparent mismatch with the modern world is intrinsic to the religion itself or is 
due to some other factors - including the decay of its defining and vital forces" (xviii-xiv). He thus laments the decay of inner Islamic spirituality which had "seamlessly integrated the sacred with the profane in the quotidian experience of a huge number of people" (270).

Allawi begins by posing three important questions:

First, could one speak of a single Islamic civilisation any longer, or had Islam broken down irretrievably into loosely connected cultural, national and ethnic units? Secondly, is a specifically Islamic civilisation a recurrent or repeatable possibility, or has it been, as the critics and sceptics would argue, forever lost? Thirdly, under what conditions can Islam's civilisational presence return to the modern world? However, above all such concerns, there is a fundamental issue central to Islam and other world religions: can a modern society, with all its complexities, institutions and tensions, be built on the vision of the divine? (xiv)

He clarifies why the core of Islamic civilisation differs from other civilisations - especially from the dominant globalising world order.

Islam forged a civilisation which was unique and easily recognisable. . . At its heart was an act of willing submission - the literal meaning of 'Islam' - to the divine reality from which all manifestations of its civilisation ultimately derived. This ideal has remained intact ever since the inception of the religion, and in the final analysis it has been the bulwark which has so far stood against the dissolution of Islam into modernity. The transcendental ideal has remained constant across the different cultural traditions which make up the world of Islam. This has been frequently overlooked: the fact of Muslims' intrinsic diversity has overshadowed their unity. ... Islamic civilisation, almost by definition, has to acknowledge the role of the transcendent (or the sacred, or the divine: call it what you will) in its make-up. If that element is absent, then Islam cannot be forced into the dynamics of modernity without its integrity being affected. (xiv)

He next provides in chapters 1-3 a historical overview of the shocks suffered by Islam over the past two centuries in its encounter with expanding Western powers followed by forces of technological scientific modernity. This part brings us up through the 1970s when the "counter-revolution of Islam" emerges aiming at "recovering the vital energies of Islamic civilisation", an ongoing process with no final resolution in sight. Chapters 4-5 examine the transformation in the fundamental values of Islam that occurred during the past two centuries, when "Islam was gradually 'de-sacralised" affecting whole aspects of how Muslims think and believe. Chapters 6-10 treat in fascinating detail the external aspects of "the erosion of Islamic civilisational space on power, institutions, politics, values, economic life, and culture and society." 
While recent debates over the future of Islam have focused on these areas, Allawi also highlights "the ethical and spiritual dimension to the question of whether a uniquely Islamic order can ever be recreated again." The thrust of his concise presentations of both inner aspects of ideas and values, and the outer aspects of institutions, laws, governance and culture, is to place before the reader the dire urgency now confronting Muslims. (xvi) "The inner dimensions of Islam no longer have the significance or power to affect the outer world in which most Muslims live" (xvi). Later he writes, "The quest for continuous material improvement, a rising standard of living, and an almost fetishistic belief in the power of science and technology is now a nearly universal condition. . . . Muslims can continue to rail against the excesses of the modern condition, but their objections are useless if their daily lives and aspirations are only a minor variant of the global standard" (271).

In his final pages, titled "What do Muslims Want?" (270-273), Allawi evokes the anguish experienced by Muslims over the loss of authenticity in their lives, their sense that immorality is increasing, and their inner ambiguity over the dominating influence of Western values in their societies. He points to the inherent contradiction of their present situation: "The majority of Muslims continue to resist a wholesale capitulation to the standards and values of modern western societies, but without knowing precisely what their resistance actually implies....The certainty of Islam becomes the only lasting element that is seen to be reliable and consistent. It is still embedded in the collective unconsciousness of all Muslims. Islam offers an inner certainty to Muslims, but its outer expression as a civilisation has been severely curtailed or abandoned. The inherent equilibrium demanded by Islam between the Muslim's inner and outer lives has been disrupted."

Allawi concludes: "So the entire argument as to whether Islam is in conflict with modernity or vice versa is false. The issue is whether Muslims want to create and dwell in a civilisational space which grows out of their own beliefs without disrupting the world of others. ... The revolt of Islam is doomed to fail if it does not find an outer expression of the faith at all the levels of civilisation." Reminding us of the pervasive secularising effect of increased affluence and economic power which reduces the cherished values of social virtues in practice to private personal ethics, he warns that reformists who call for "wholesale adoption of the institutions and processes of modern technological societies" would ensure a final break between the sacred and the profane in the world of Islam. This results in a hollow simulation of Islam "with a deceptive cultural distinctiveness, one which has effectively merged with the dominant order."

If Muslims want the very things that modern technological civilisation promises, then "they have to acknowledge the roots of this civilisation in order to 
become an active and creative part of it. Otherwise they will simply be a parasitic attachment to it." However if Islam accepts these premises, "then the best that Muslims can do is to 'package' the final products of their civilisation in ways which may be culturally or politically acceptable to their own societies. They can even participate in the dominant civilisational order and accept the risks that it might fatally undermine whatever is left of Muslims' basic identity and autonomy. This appears to be the path that the richer societies of the Muslim world have chosen for themselves." Examples are the Arab Gulf and Malaysia.

On the other hand radical Islamists, as well as the ranks of conservative or rationalist Muslims, delude themselves by thinking that using the filter of Shari'ah to enable "picking and choosing from the menu of change, a happy compromise between Islam and what is acceptable from modernity can be fashioned." Allawi correctly observes: "This approach, which has been entertained for over a century, has neither produced satisfactory material progress nor strengthened the foundations of Islamic civilisation in any way." Why has this conventionally approved method missed the mark? Because "the change they are facing is a product of a different and ascendant civilisational order. It can only be internalised successfully if it is refashioned, and then transcended, in a uniquely Islamic framework."

How best to regenerate a transformed Islamic civilisation? His final point: "If Muslims want to live an outer life which is an expression of their innermost faith, they have to reclaim those parts of their public spaces which have been conceded to other world views over the past centuries." Otherwise, Allawi warns: "Islam will simply be another motif in a consumer-driven, self-obsessed, short attentionspan global culture; another 'player' in the marketplace for ideas and religions. The retreat of Islam into the private, individual sphere will be complete."

\section{Notes}

* $\quad$ Karim D. Crow, Principal Fellow at IAIS Malaysia.

** Ali Allawi graduated from MIT in 1968 with a BSc in Civil Engineering, with postgraduate studies at the London School of Economics in Regional Planning, then his MBA from Harvard University in 1971. Dr Allawi worked as an investment officer in the Capital Markets Department of the World Bank/IFC Group, consultant to the Arab Fund in Kuwait, and in 1978 co-founded the merchant bank Arab International Finance in London. He held research positions at ISTAC in Kuala Lumpur, and at St. Antony's College, Centre for Middle Eastern Studies, Oxford University. He served in 2003 as Minister of Trade of Iraq under the Iraq Governing Council, then became Iraq's first postwar civilian Minister of Defence in 2004. In April 2005 he was appointed Minister of Finance and held that post until May 2006 when he returned to private life. He has lectured widely on Iraq and served on numerous international political and economic forums from Davos to Chatham House, and received several notable awards for public diplomacy. He published the Occupation of Iraq (Yale University Press, 2007) and The Crisis of Islamic Civilization (Princeton University Press, 2009). He currently serves as Senior Visiting Fellow at the Carr Center, Kennedy School of Government, Harvard University.

1. The Crisis of Islamic Civilization (New Haven: Yale UP, 2009). 